Journal of Engineering and Applied Sciences 7 (1): 79-85, 2012

ISSN: 1816-949X

(C) Medwell Journals, 2012

\title{
Rainfall Trends in Uyo-Akwa Ibom State and its Implication on Urban Flooding
}

\author{
C.E. Udosen \\ Department of Geography and Regional Planning, University of Uyo, Uyo, Nigeria
}

\begin{abstract}
Available records of daily rainfall data recorded for a period of 34 years (1977-2010) from the Agro-meteorological station of the University of Uyo was subjected to rigorous statistical analysis such as measures of central tendency and variability, time series analysis and Spearman rank order statistics. Data on extreme daily rainfall, water balance and flood occurrences were collected for analysis. The annual rainfall was analysed for variability using standardized rainfall anomaly index while recurrence intervals were analysed using Gumbell Extreme Probability Theory. The results of the analysis indicate annual rainfall ranges from $1599.5 \mathrm{~mm}$ in 1983 to $3855.5 \mathrm{~mm}$ in 1977 with a mean of $2466.6 \mathrm{~mm}$, concentration of rainfall in the months of April-October with mostly high intensity prolonged rainstorm. The results also show a remarkable continuous downward trend in annual rainfall amounts that the period between 1977 and 1979 witnessed the highest frequencies of extreme rainfall events and flood frequencies that major floods were associated with high recurrence intervals and that the seasonality of flooding in Uyo occurs between April and October. This study provides a database that could be employed in flood control in a data poor country such as Nigeria.
\end{abstract}

Key words: Rainfall, flash floods, trends, variability, index, Uyo

\section{INTRODUCTION}

In Nigeria, the literature is replete with studies on rainfall and their implication for flood frequency (Udosen, 1987; Ologunorisa, 2004; Oriola, 1994; Olaniran, 1983; Odekunle, 2001).

As is true throughout most of Southern Nigeria, there is a strong direct relationship between urban floods and the occurrence of high intensity prolonged rainstorms. This means that an understanding of the trends in rainfall variability with respect to flooding is imperative. Increasing flood risk is now being recognized as the most important direct consequence of climate change in most parts of the world. This has prompted public debate on the apparent increased frequency of extreme and in particular, on perceived increases in rainfall intensities (Dyson, 2002). Several studies have adduced extreme rainfall to be the major cause of flood worldwide (Gobo,1988; McEwen, 1989; Oriola, 1994; Babatalola, 1996; Fowler and Kilsby, 2003; Odekunle, 2001; Ologunorisa, 2004).

Other studies have identified the characteristics of extreme rainfall that are associated with flood frequency to include duration, intensity, frequency, seasonality, variability, trend and fluctuation (Olaniran, 1983; Ologunorisa, 2004; Ologunorisa and Diagi, 2006). Attempts have also been made to employ GIS in flood management in Southern Nigeria (Udosen, 2010) and remote sensing in the management of floods in Asia (Sanyal and $\mathrm{Lu}, 2004$ ). The present study attempts to examine recent changes in rainfall pattern/trends and its implication on urban flood frequency in Uyo, South Eastern Nigeria. The study was specifically designed to verify some general regional patterns which can be expressed in terms of variability (inter-annual), trends (upward and downward) and persistence, a typical inertia which affects many hydrologic processes (Fig. 1).

\section{MATERIALS AND METHODS}

Study area: Uyo, the capital of Akwa Ibom state is located between latitudes $4^{\circ} 54^{\prime} \mathrm{N}$ and $5^{\circ} 03^{\prime} \mathrm{E}$ and longitudes $7^{\circ} 57^{\prime}$ and $8^{\circ} 03^{\prime} \mathrm{E}$. The study area has climate characteristics that could be described as humid tropical, i.e., Af climate type based on Koppen's classification. There are two main season; the dry season (November-February/March) when the Northeast trade wind from the desert blows across the area.

The rains come between March and October and in some wet years, it may extend into early November when the ITD moves Southwards. More importantly, the study area has undulating terrains which predisposes it to frequent occurrence of flash floods.

Data collection and analytical techniques: The data used for this study are from secondary sources. These include data on rainfall, water balance and flood occurrence in Uyo town. The rainfall data used are of two types-annual rainfall and extreme daily rainfall. The annual rainfall data covered the period from 1977-2010 while the extreme daily 


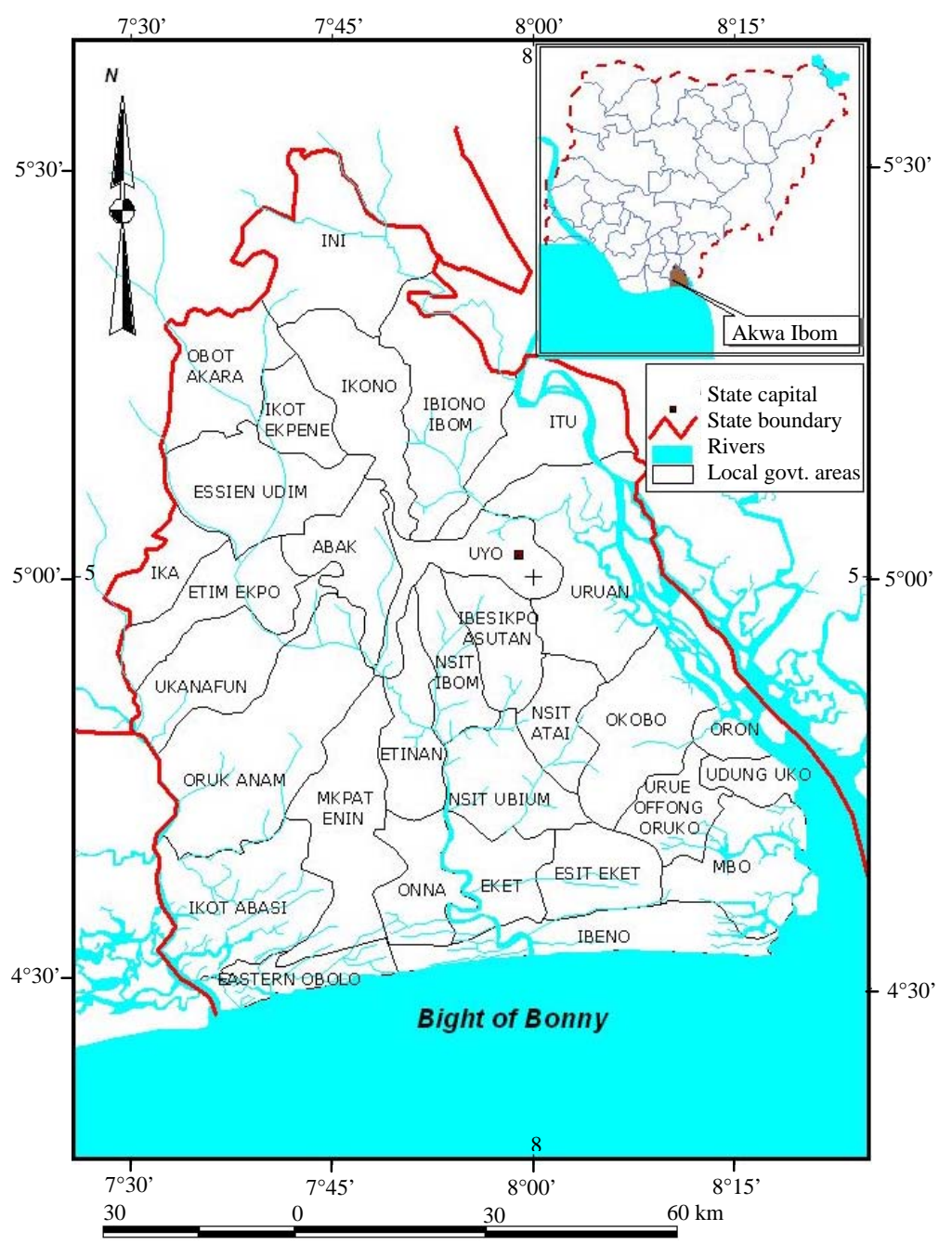

Fig. 1: The study area

rainfall data spanned 1979-2010. The water balance records were for the period 1981-1997. Information on flood occurrence for the corresponding period was collected from local newspaper reports and past history of flood occurrence in the study area were also sourced from the relevant literature. Records of annual rainfall in Uyo were collected from the report of Udosen (2008a, b) and the Agrometeorological station, University of Uyo. The extreme daily rainfall was also extracted from the archives of the station. Basic statistical techniques were employed to determine the means and standard deviations of the data. The annual rainfall trend was determined using Spearman rank order statistics. The Standardized rainfall Anomaly Index (SAI) was used in the analysis of annual rainfall variability. The $\mathrm{SAI}$ is given as:

$$
\mathrm{SAI}=\frac{\mathrm{X}_{\mathrm{i}}-\mathrm{X}^{-}}{\mathrm{SD}}
$$

Where:

$\mathrm{X}=$ The annual rainfall total

$\mathrm{X}^{-}=$The mean of the entire series

$\mathrm{SD}=$ The standard deviation from the mean of the series

The extreme daily rainfall characteristics including the magnitude-frequency, seasonality and duration were also computed. The Gumbel extreme value distribution was used to determine the magnitude and frequency of extreme rainfall and hence, the recurrence interval. The method of recurrence interval used in this study is usually employed in the description of probability of recurrence or incidence of extreme events (Dury, 1964; Lang, 1997; Versace and Ferrari, 1997). It is primarily concerned with prediction such as the estimation of the magnitude of the daily, monthly and annual rainfall total likely to be exceeded on average say once during 50 years. Generally, 
there are two ways by which recurrence interval of rainfall data is carried out; namely, partial series and annual series analyses. The partial series involves the extraction of all values above a given magnitude from the record of daily rainfall over the years of study. The annual series on the other hand involves the selection of the maximum values occurring in each year. The more commonly employed method is the annual series and it was employed in this study to determine various return periods. The procedures involve arranging the annual series in descending order of magnitude. The Recurrence Interval (RI) is determined thus:

$$
\mathrm{RI}=\frac{\mathrm{N}-\mathrm{I}}{\mathrm{M}}
$$

Where:

$\mathrm{N}=$ No. of events in the series

$\mathrm{M}=$ Rank of individual event

$\mathrm{RI}=$ The return period expressed in years

The rainfall values were then plotted against their recurrence intervals on Gumbel's probability paper and a line of best fit on the scatter diagram was drawn as described by Dury (1964). The water budget was determined by Thornthwaite's Method.

\section{RESULTS AND DISCUSSION}

The annual rainfall trend over the study period was shown to have a negative curve:

$$
Y=-5.602 x+136.36
$$

With low coefficient of determination of 0.009 (Fig. 2). The significance of the trend was tested by the Student's t-test and was found not to be significant at $95 \%$ confidence level. This is an indication that the period is too short to depict a downward trend (significant decline in rainfall) in annual rainfall in Uyo town, Ologunorisa was able to depict a downward trend using a 77 years records at Makurdi in Northern Nigeria. However, analysis of the annual rainfall fluctuation in Uyo was achieved by 5 years (1977-2010) running mean (Fig. 3). In terms of actual annual rainfall total, the wettest years in the period of record were 1977 (3855.5 mm), 1979 (3825.4 mm), 2006 (3373.7 mm), 2007 (3308.2 $\mathrm{m})$ and 1978 $(3270.7 \mathrm{~mm})$ and the driest years were $1983(1599.5 \mathrm{~mm})$, 1984 (1878.9 mm), 2003 (1894.3 mm), 1986 (1905.6 mm) and 1997 (1921.3 mm).

When a 5 years running mean was put through the annual total rainfall series, fluctuations involving increased annual rainfall totals were most prominent in the

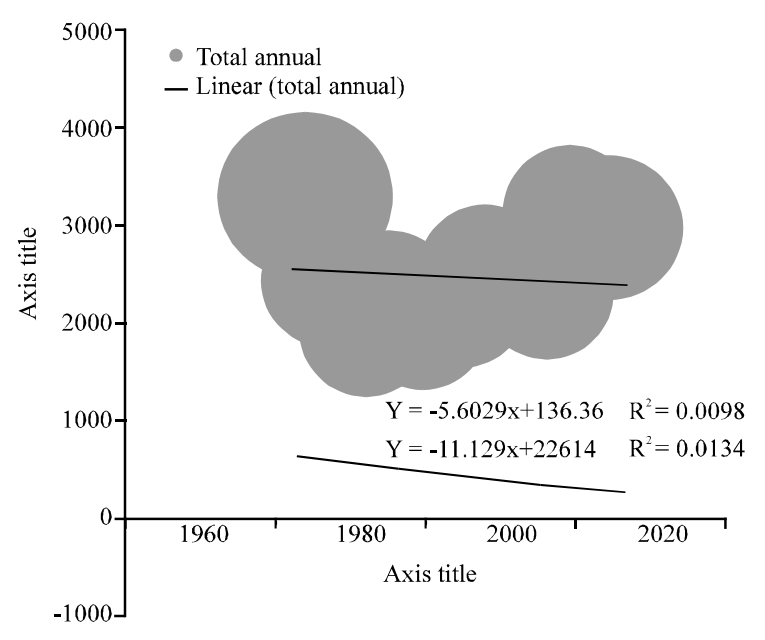

Fig. 2: Annual rainfall trend in Uyo (1977-2010)

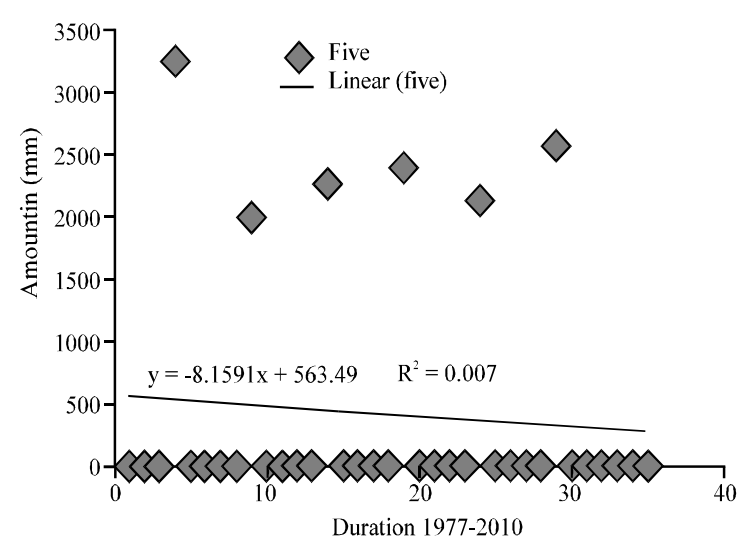

Fig. 3: Five year running mean (1977-2010)

Table 1: Periods of remarkable deterioration in rainfall for Uyo (1977-2010) Duration (years) $\quad$ Remarkable deterioration 1st 8 2nd

4 3rd 1981-1988 $1990-1993$ 2000-2004

Table 2: Periods of above average rainfall for Uyo (1977-2010) Duration (years) 1 st 4 2nd 4 Rainfall (above average)

1977-1980 2005-2008

periods $1977-1980(+393.8$ to $+1388.9 \mathrm{~mm})$ and $2005-2010$ $(+266$ to $+907.1 \mathrm{~mm})$. Fluctuations involving decreased rainfall totals were also depicted at the period 1981-1988 (the worst deviation from the mean in the period) and 2000-2004 (Table 1 and 2 and Fig. 3). Table 1 and 2 also revealed that the periods 1977-1980 and 2005-2011 (broken by 2009) was characterized by more years of above 


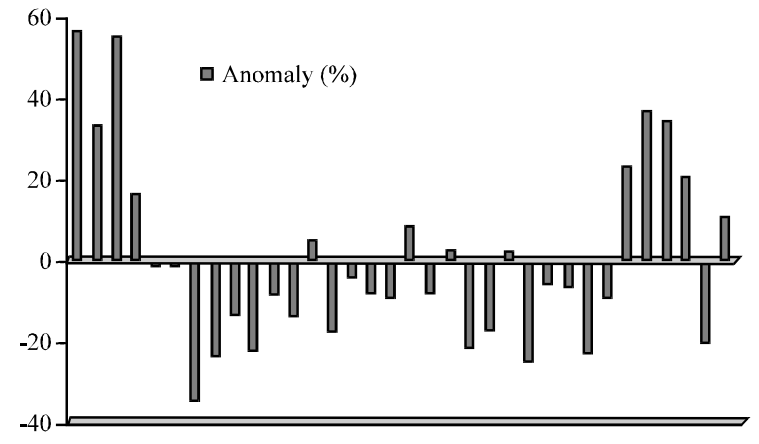

Fig. 4: Annual rainfall variability in Uyo (1977-2010)

average rainfall. The periods 1981-1988; 1990-1993 and 2000-2004 were however, characterized by a period of below average rainfall, an indication that the climate of Uyo generally has very low annual rainfall in years ending with three, i.e., 1973 (Sahelian drought of 1968-1974), 1983, 1993 and 2003. Figure 4 shows that Uyo has passed through wet and dry sequences over the study period. This station does not exhibit persistence in the pattern of wet and dry conditions except the dry spells of 1981-1988. The remarkably below long-term means were recorded in the period 1981-2004 with $1983(-35.2 \%)$ as the year of highest negative deviation. It is apparent from Fig. 4 that the occurrence of dry years was more than the wet ones from 1977-2010. For the past 20 years (1990-2010) however, the period 2005-2010 (except 2009) was marked by positive departures from the mean. These findings confirm the results of earlier study by Yousef and Ghilly (2000), they anticipated that there is a considerable probability that drought will occur in the EI Sahel zone in 2005. This forecast was correct as drought actually occurred between 1981 and 1988. Batterbury (2001) noted the occurrence of famine and dislocation on a massive scale from 1968-1974 and again in the early and mid 1980's and blamed it on two spikes in the severity of the 1960-1980's drought period (Fig. 5).

The expected recurrence intervals of the extreme daily rainfall magnitudes are showed in Table 3 which shows the values of extreme daily rainfall and their recurrence interval in Uyo between 1979 and 2010. The characteristic of the increases, the magnitude of rainfall events increase at a lesser rate until a point is reached where lengthening of recurrence interval will involve no increase in magnitude. From Table 4 for instance, it can be inferred that daily rainfall event of $180 \mathrm{~mm}$ which is the highest in the series can be expected to occur once in every 33 years.

Whereas, daily rainfall amount of $155.0 \mathrm{~mm}$, the third in magnitude can be expected to occur in every 11 years. However, for extreme daily rainfall amounts of lesser

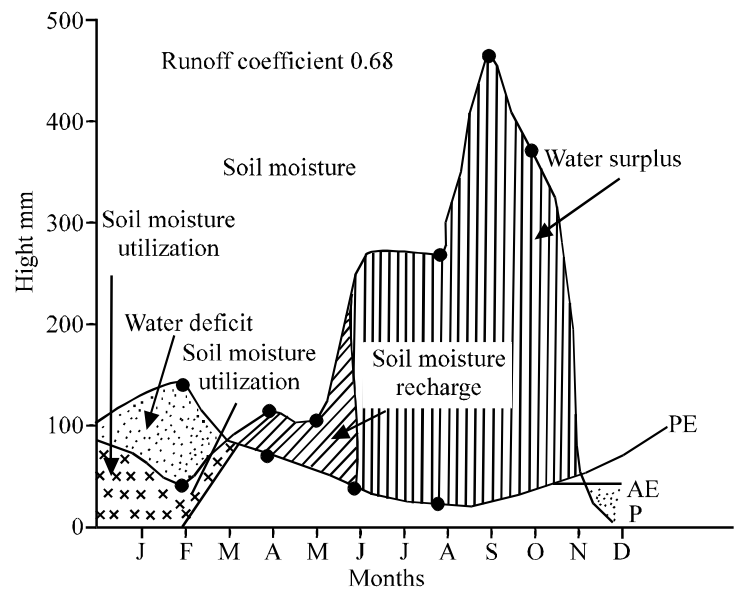

Fig. 5: Water balance at Iba Oku catchment computed from meteorological records (1992)

Table 3: Annual rainfall variability in Uyo (1977-2010)

\begin{tabular}{|c|c|c|c|}
\hline Years & Annual total (mm) & Anomaly (mm) & Anomaly (\%) \\
\hline 1977 & 3855.5 & +1388.9 & +56.30 \\
\hline 1978 & 3270.7 & +804.1 & +32.60 \\
\hline 1979 & 3825.4 & +1358.8 & +55.10 \\
\hline 1980 & 2860.4 & +393.8 & +15.90 \\
\hline 1981 & 2426.8 & -39.8 & -1.60 \\
\hline 1982 & 2442.5 & -24.1 & -0.98 \\
\hline 1983 & 1599.5 & -867.1 & -35.20 \\
\hline 1984 & 1878.9 & -587.9 & -23.80 \\
\hline 1985 & 2132.6 & -334.0 & -13.50 \\
\hline 1986 & 1905.2 & -561.4 & -22.80 \\
\hline 1987 & 2251.4 & -215.2 & -8.70 \\
\hline 1988 & 2115.0 & -351.6 & -14.30 \\
\hline 1989 & 2588.7 & +122.1 & +4.95 \\
\hline 1990 & 2027.1 & -439.5 & -17.80 \\
\hline 1991 & 2346.7 & -119.9 & -4.90 \\
\hline 1992 & 2256.8 & -209.8 & -8.50 \\
\hline 1993 & 2229.5 & -237.1 & -9.60 \\
\hline 1994 & 2668.7 & +202.1 & +8.20 \\
\hline 1995 & 2264.4 & -202.2 & -8.20 \\
\hline 1996 & 2520.7 & +54.1 & +2.20 \\
\hline 1997 & 1921.3 & -545.3 & -22.10 \\
\hline 1998 & 2033.8 & -432.8 & -17.50 \\
\hline 1999 & 2508.5 & +41.9 & +1.70 \\
\hline 2000 & 1840.8 & -625.8 & -25.40 \\
\hline 2001 & 2317.2 & -149.4 & -6.10 \\
\hline 2002 & 2301.5 & -165.1 & -6.70 \\
\hline 2003 & 1894.3 & -572.3 & -23.20 \\
\hline 2004 & 2221.6 & -24.5 & -9.90 \\
\hline 2005 & 3030.5 & +563.9 & +22.90 \\
\hline 2006 & 3373.7 & +907.1 & +36.70 \\
\hline 2007 & 3308.2 & +841.6 & +34.10 \\
\hline 2008 & 2970.6 & +504.0 & +20.40 \\
\hline 2009 & 1944.1 & -522.5 & -21.20 \\
\hline 2010 & 2732.6 & +266.0 & +10.80 \\
\hline 2011 & - & - & - \\
\hline
\end{tabular}

Extracted from University of Uyo station (1977-2010)

magnitudes such as 90.0 and $61.6 \mathrm{~mm}$, their recurrence intervals are 1.32 and 1.03 years, respectively. Also, extreme rainfall in excess of $110 \mathrm{~mm}$ is expected every 2 years. Furthermore, it was revealed in another study that rainfall in Uyo (1977-2006) is mainly convectional hence, 
Table 4: Magnitude-frequency of extreme daily rainfall events in Uyo (979-2010)

\begin{tabular}{|c|c|c|c|}
\hline Years & $\begin{array}{c}\text { Rainfall } \\
\text { amount (mm) }\end{array}$ & Rank & $\begin{array}{l}\text { Re-currence } \\
\text { interval (y ear) }\end{array}$ \\
\hline 1979 & 180.0 & 1 & 33.0 \\
\hline 2005 & 161.2 & 2 & 16.5 \\
\hline 2009 & 155.0 & 3 & 11.0 \\
\hline 2006 & 151.0 & 4 & 8.25 \\
\hline 2010 & 148.4 & 5 & 6.60 \\
\hline 2004 & 135.5 & 6 & 5.50 \\
\hline 2008 & 130.0 & 7 & 4. 71 \\
\hline 1996 & 120.0 & 8 & 4.13 \\
\hline 1992 & 119.3 & 9 & 3.67 \\
\hline 1993 & 118.8 & 10 & 3.30 \\
\hline 2007 & 117.6 & 11 & 3.00 \\
\hline 1989 & 115.1 & 12 & 2.75 \\
\hline 1990 & 114.0 & 13 & 2.54 \\
\hline 1988 & 113.8 & 14 & 2.36 \\
\hline 1981 & 110.3 & 15 & 2.20 \\
\hline 1994 & 110.1 & 16 & 2.06 \\
\hline 2002 & 110.0 & 17 & 1.94 \\
\hline 1980 & 106.4 & 18 & 1.83 \\
\hline 1997 & 100.4 & 19 & 1.74 \\
\hline 2000 & 100.4 & 20 & 1.65 \\
\hline 1998 & 100.0 & 21 & 1.57 \\
\hline 1985 & 94.6 & 22 & 1.50 \\
\hline 1982 & 93.9 & 23 & 1.43 \\
\hline 1991 & 92.6 & 24 & 1.38 \\
\hline 1999 & 90.0 & 25 & 1.32 \\
\hline 2001 & 82.1 & 26 & 1.27 \\
\hline 1995 & 78.0 & 27 & 1.22 \\
\hline 1987 & 76.7 & 28 & 1.18 \\
\hline 1986 & 74.0 & 29 & 1.14 \\
\hline 2003 & 70.4 & 30 & 1.10 \\
\hline 1984 & 66.2 & 31 & 1.06 \\
\hline 1983 & 61.6 & 32 & 1.03 \\
\hline
\end{tabular}

rainstorms of $>25.4 \mathrm{~mm}$ contribute a total of $58.7 \%$ of annual rainfall (Udosen, 2008a). In some wet years, the contribution of rainstorms particularly cloudburst rains $(>100 \mathrm{~mm}$ ) could be above $80 \%$ as in $1977(84.1 \%)$ and $1979(80.4 \%)$. Udosen (2008b) also reported that there is a declining trend in the proportion of light/moderate rains (frequency of rainfall) and an increasing trend in the proportion of total rainfall due to rainstorms of $>100 \mathrm{~mm}$ in recent years. This is one major reason for the frequent flood in Uyo recently. Analysis of the seasonality of extreme daily rainfall event shows that the months of June and August to October had the highest frequency of 6 events and a total percentage of 72.7 in the series (Table 4 and 5). Table 5 also reveals that although, the month of July came next to August to October with five extreme rainfall events, the total amount of extreme rainfall received in April were quite high, i.e., 180, 155 and $92.6 \mathrm{~mm}$, respectively. The infrequent occurrence of prolonged rainstorms at the beginning of wet season in a feature of the thundery rains caused by squall lines which are usually characterized by high intensities at the beginning of the rain events-advanced storms. This may not be as destructive as the delayed, intermittent and composite storms of associated with the months of
Table 5: Extreme rainfall series in Uyo (1979-2010)

\begin{tabular}{|c|c|c|c|}
\hline Years & $\begin{array}{c}\text { Annual } \\
\text { total (mm) }\end{array}$ & Days & $\begin{array}{l}\text { Extreme rainfall } \\
\text { amount (mm) }\end{array}$ \\
\hline 1979 & 3825.4 & 22 April & 180.0 \\
\hline 1980 & 2860.4 & 22 August & 106.4 \\
\hline 1981 & 2426.8 & 6 September & 110.3 \\
\hline 1982 & 2442.5 & 11 June & 93.9 \\
\hline 1983 & 1599.5 & 16 July & 61.6 \\
\hline 1984 & 1878.9 & 25 June & 66.2 \\
\hline 1985 & 2132.6 & 18 September & 94.6 \\
\hline 1986 & 1905.2 & 10 July & 74.0 \\
\hline 1987 & 2251.4 & 30 May & 76.7 \\
\hline 1988 & 2115.0 & 15 September & 113.8 \\
\hline 1989 & 2588.7 & 8 July & 115.1 \\
\hline 1990 & 2027.1 & 10 August & 114.0 \\
\hline 1991 & 2346.7 & 27 April & 92.6 \\
\hline 1992 & 2256.8 & 11 August & 119.3 \\
\hline 1993 & 2229.5 & 1 August & 118.8 \\
\hline 1994 & 2668.7 & 27 June & 110.1 \\
\hline 1995 & 2264.4 & 27 October & 78.0 \\
\hline 1996 & 2520.7 & 19 August & 120.0 \\
\hline 1997 & 1921.3 & 26 October & 100.4 \\
\hline 1998 & 2033.8 & 7 June & 100.0 \\
\hline 1999 & 2508.5 & 29 October & 90.0 \\
\hline 2000 & 1840.8 & 26 October & 100.4 \\
\hline 2001 & 2317.2 & 21 June & 82.1 \\
\hline 2002 & 2301.5 & 13 September & 110.0 \\
\hline 2003 & 1894.3 & 7 October & 70.4 \\
\hline 2004 & 2221.6 & 5 September & 135.5 \\
\hline 2005 & 3030.5 & 2 July & 161.2 \\
\hline 2006 & 3373.7 & 10 September & 151.0 \\
\hline 2007 & 3308.2 & 10 October & 117.6 \\
\hline 2008 & 2970.6 & 15 June & 130.0 \\
\hline 2009 & 1944.1 & 21 April & 155.0 \\
\hline 2010 & 2732.6 & 23 August & 148.4 \\
\hline
\end{tabular}

July to October due to antecedent soil moisture conditions. The least extreme rainfall $(61.6 \mathrm{~mm})$ in the series is that of the driest year in the series July 16, 1983, Olaniran (1983) has reported that heavy rains induce flooding when they occur about three or more times in a month during the period of moisture surplus. Based on this factor, the water budget graph of Uyo was plotted using monthly totals of rainfall and evapotranpiration for the period 1981-1997. The water budget graph depicts the seasonal trend in soil moisture status.

The month of August was observed to have the highest moisture surplus. Excess soil moisture was however received from May to October, the period during which flooding is more likely to occur. The typical water balance computed for Uyo showed that the annual rainfall is in excess of the potential evaporation. The results of the computed water balance for 17 years recorded the runoff coefficient range of $0.62-0.89$ with mean of 0.73 and standard deviation of 6.89 (Udosen, 2008a).

Annual evaporation was $1350.1 \mathrm{~mm}$ while the computed annual water surplus was $1529.7 \mathrm{~mm}$. The implication of this high rainfall excess over evaporation is the availability of water for surface runoff (the best predictor of flooding). Usually, flooding in the study area is usually severe in the month of June due to high soil 
moisture but common during the peak of the wet season between June and September. Unfortunately, this period is also characterized by very high values of rainfall erosivity. However from the analysis of rainfall magnitudes and estimated recurrence interval, it was found that available records of flood events corresponded to rainfall events of high recurrence intervals. For instance, the flood events of 25th June 1999; 3rd August 2000 and 11 th September 2002 corresponded to rainfalls with $6.7,27.0$ and 5.4 years recurrence intervals, respectively. Major floods were mostly associated with high recurrence interval storms.

Although, annual rainfall fluctuation in Uyo was found to be in progressive decline, the period 2005-2010 was marked by positive deviation from the mean. This period of positive deviation from the mean corresponded to periods of increased frequency of heavy rainfalls and flooding in the area.

This is agrees with the findings of Babatolola (1996) that heavy rainfall events are more likely to reflect annual changes than light or moderate falls. It therefore implies that it is these heavy rainfall events that result in overland flow and hence, frequent inundation of roads/streets in Uyo. The seasonal trend in soil moisture status in Uyo indicate that the surplus water will first be utilized in recharging the underground moisture reserve from May and should be available for rapid run-off from July to October. However, the month of August has been shown to be the month with the highest soil water surplus as well as having the most frequent events of extreme daily rainfall in the series (Table 5). Thus, seasonality of extreme rainfall evidently had important implications for flood response.

The recent flood records of 9th July, 2011 and 13th August, 2011 are further indicators that floods are to be expected to occur mostly from July/August. Udosen (2008a) established a statistically significant relationship between rainstorms and runoff in the study area $(\mathrm{r}=0.53)$. The low percentage is due to other factors such as slope steepness, curvature and length, land-use intensity, provision/maintenance of roadside drains and amount/type of vegetation. In addition, other attributes of rainfall also influence the likelihood of flooding for instance (Udosen, 2008b) noted that rainstorms/year, mean monthly rainfall, frequency of rainfall/month and total annual rainfall accounted for $46 \%$ of variance in runoff (multiple regression coefficient of 0.68). The distribution of intensities (delayed, advanced, intermittent and composite storms) during a rain event is equally important in flooding due to antecedent moisture conditions of the soil (Table 6).
Table 6: Seasonality of extreme rainfall in Uyo Months Frequency (days) Remarks

April $\quad 03 \quad$ Due mainly to squall line

May $\quad 01 \quad$ Soil moisture recharge

June $\quad 06 \quad$ Beginning of water surplus

July $\quad 05 \quad$ Likelihood of flooding

August $\quad 06 \quad$ No August break

September $06 \quad$ High frequency of

prolonged intense rainstorms/peak of surplus

October

$06 \quad$ Recession limp of surplus water

\section{CONCLUSION}

The results from this study have revealed remarkable continuous downward trend in annual rainfall amounts in Uyoi from 1981-2004, breaking only from 1989, 1994 and 1996. The period of recent upward trend (2005-2010) however, recorded the highest frequencies of extreme rainfall events with corresponding flood frequencies. It is also apparent from the analysis that Uyo is getting drier but receiving unprecedented heavy rainfalls. It is therefore not the annual rainfall total that is an important cause of increased flood frequency in Uyo but the percentage of it that falls as heavy falls. As is true throughout most of Southern Nigeria there is a strong direct relationship between urban floods and the occurrence of high intensity prolonged rainstorms. This means that an understanding of the trends in rainfall variability respect to flooding is imperative.

\section{REFERENCES}

Babatolola, J.S., 1996. Recent changes in rainfall patterns and its implication for flood occurrence in Ondo, Nigeria, Ondo. J. Arts Social Sci., 1: 125-136.

Batterbury, S., 2001. The Sahel region: Assessing progress twenty-five years after the great drought. Proc. RGS-IBG Conf. Global Environ. Change, 11: 1-95.

Dury, G.H., 1964. Some result of magnitudes-frequency analysis of precipitation. Aust. Geog. Stud., 2: 21-34.

Dyson, L.L., 2002. The Heavy Rainfall and Flood of February 2000: A Synoptic Overview of Southern Africa Floods of February 2000. Department of Civil Engineering, University of Pretoria, Pretoria.

Fowler, H.J. and C.G. Kilsby, 2003. Implications of changes in seasonal and annual extreme rainfall. Geophys. Res. Lett., 30: 1-4.

Gobo, A.E., 1988. Relationship between rainfall trends and flooding in the Niger-Benue river Basin. J. Meteorol., 13: 132-133.

Lang, M., 1997. New development with AGREGEE. A Statistical Model Using Hydrometeonelogical Information. FRIEND Project, H-5-5 (IHPIV). 
McEwen, L. J., 1989. Extreme rainfall and its implications for flood frequency: A case study of the middle river Tweed basin, Scotland. Trans. Inst. Br. Geograph., 14: $287-298$.

Odekunle, T.O., 2001. The magnitude-frequency characteristic of rainfall in Ondo, Southwestern Nigeria. Ife Res. Publ. Geogr., 8: 36-41.

Olaniran, J.O., 1983. Flood generating mechanism in Ilorin, Nigeria. Geo-J., 7: 271-277.

Ologunorisa, E.T., 2004. Rainfall and flood prediction in the Niger Delta, Nigeria. Proceedings of the International Conference on Hydrology, July 12-16, 2004, Science and Practice for the 21st Century, London, UK., pp: 354-360.

Ologunorisa, E.T. and P.N. Diagi, 2006. Extreme rainfall and its implication for flood frequency in the Niger Delta: A case study of Warri. Niger. J. Trop. Geogr., 1: $35-44$.

Oriola, E.O., 1994. Strategies for combating urban flooding in a developing nation: A case study of Ondo, Niger. The Environmentalist, 14: 57-62.
Sanyal, J. and X.X. Lu, 2004. Application of remote sensing in flood management with special reference to Monsoon Asia: A review. Nat. Hazards, 33: 283-301.

Udosen, C.E., 1987. Flood problems in Uyo urban. B.Sc. Thesis, Department of Geography and Regional Planning, University of Uyo.

Udosen, C.E., 2008a. Rainfall Analysis and Forecasting in Akwa Ibom State. Unwana Graphics Press, USA.

Udosen, C.E., 2008b. Gully Erosion in Ikpa River Basin : A Threshold Phenomenon. Time Communications, Lagos, Nigeria, Pages: 295.

Udosen, C.E., 2010. GIS as a spatial decision support system for flood management in a built-up area of Uyo, Akwa Ibom State. Int. J. Social Policy Res. Dev., 1: $62-70$.

Versace, P. and E. Ferrari, 1997. Regional hierarchical approach to flood frequency analysis. FRIEND Project, H-5-5 (IHPV).

Yousef, S. and L.O.M. Ghilly, 2000. Alert El Sahel countries; drought is approaching. Cairo University, Egypt, September, 2000, pp: 209-221. http://virtual academia.com/pdf/cli209_220.pdf. 